\title{
E SE JESUS FOSSE GAY, ZUMBI OU FOSSE SALVO PELO EXTERMINADOR DO FUTURO? TEOLOGIA REFLEXIVA POPULAR A PARTIR DA PRODUÇÃO MIDIÁTICA VIA INTERNET
}

\section{Jesus might have been gay, zombie or have been saved by the Terminator? \\ Theology Reflective Popular media production through the internet.}

Y si Jesús hubiera sido gay o zombie? o si hubiera sido ayudado por el Terminator? Teología Popular reflexivo de la producción de medios de Internet.

\section{Luiz Vadico}

Universidade Anhembi Morumbi

vadico@hotmail.com

\section{Resumo}

Este artigo parte da análise de três vídeos disponíveis no site Youtube: Jesus Christ! The Musical, de Javier Prato (2007), The Greatest Action Story Ever Told, produzido pela Mad TV (2006) e The Passion of Zombie Jesus, de Ira Hunter (2006). A partir dos conceitos desenvolvidos pelos teólogos Clive Marsh e William Telford, verificaremos a mensagem teológica, o público ao qual se destina, a finalidade, a imagem de Cristo gerada, a sua função e posição em relação à teologia dita tradicional. A análise central será do filme de Javier Prato. A escolha do Youtube e de vídeos feitos para a internet se deve ao grande acesso do público e por se tratarem de novas práticas sociais contemporâneas.

Palavras-chave: Cristologia. Audiovisual. Cinema. Gêneros. Hibridismo.

\begin{abstract}
This article comes from the analysis of three videos available on Youtube site: Jesus Christ! The Musical by Javier Prato (2007), The Greatest Action Story Ever Told, produced by Mad TV (2006) and The Passion of Zombie Jesus, Ira Hunter (2006). In the videos will be checked theological message, the audience to which it is intended, the purpose of these videos, the image generated from Jesus Christ, its role and position in relation to traditional theology. The analysis will focus on the film by Javier Prato. The choice of Youtube and videos made for the internet is due to great public access and because they are new contemporary social practices.
\end{abstract}

Key words: Christology. Video. Cinema. Genres. Hybridization. 


\section{Resumen}

Esto artículo proviene del análisis de tres videos disponibles en el sitio Youtube: ¡Jesucristo! El musical de Javier Prato (2007), La historia más grande jamás contada Acción, producido por Mad TV (2006) y La Pasión de Jesús del zombi, Ira Hunter (2006). En los videos se comprobará mensaje teológico, el público al que está destinado, el propósito de estos videos, la imagen generada a partir de Jesucristo, su papel y posición en relación con la teología tradicional. El análisis se centrará en la película de Javier Prato. La elección de Youtube y vídeos realizados por el Internet se debe al acceso al gran público y porque son nuevas prácticas sociales contemporáneas.

Palabras clave: Cristología. Audiovisual. Cine. Géneros. Hibridación.

\section{INTRODUÇÃO}

Este ensaio parte da análise de três vídeos disponíveis no site Youtube: Jesus Christ! The Musical, de Javier Prato (2007), The Greatest Action Story Ever Told, produzido pela Mad TV (2006) e The Passion of Zombie Jesus, de Ira Hunter (2006). A partir de alguns princípios desenvolvidos pelos teólogos Clive Marsh e William Telford, verificaremos a mensagem teológica, o público ao qual se destina, a finalidade, a imagem de Cristo gerada, a sua função e posição em relação à teologia dita tradicional. A análise central será do filme de Javier Prato. A escolha do Youtube e de vídeos feitos para a internet se deve não somente ao grande acesso do público, mas por se tratarem de novas práticas sociais ainda carentes de atenção de pesquisadores.

Iniciamos este artigo pela palavra ensaio, pois não pretendemos desenvolver uma reflexão a partir de intensa pesquisa acadêmica, mas apenas a partir da análise do produto midiático, observando as ideias teológicas que estes parecem sugerir. O que não nos isenta de críticas, mas nos isenta do desejo de participar do debate teológico tradicional, o qual respeitamos o suficiente para caminharmos à sua margem.

Isto posto, tratemos do nosso objeto. Três vídeos de curta-metragem que elaboram ou reelaboram a imagem de Jesus Cristo. São vídeos realmente curtos, nenhum deles chega a ter mais de sete minutos. Este tempo bastante limitado não permite aos seus produtores realizarem uma cristologia fílmica mais elaborada, no entanto, ainda assim é possível verificar a imagem de Cristo gerada, verificar seus significados e o sentido social desta representação.

Os três vídeos possuem propostas bastante distintas entre si, por essa razão escolhemos nos centrar em apenas um deles, não é uma escolha aleatória, está embasada num 
fato estatístico, no entanto, a análise poderia ser realizada da mesma forma com qualquer um deles. Pelo que pudemos verificar tendo em vista o numero de cópias e de acessos às mesmas, o mais popular é Jesus Christ! The Musical, de Javier Prato (2007). Javier Prato, um jovem argentino radicado nos Estados Unidos (Los Angeles) é o seu realizador; pelas informações do seu site pessoal ${ }^{1}$ sabemos que atualmente produz comerciais para a $\mathrm{TV}$, o sucesso do pequeno vídeo foi utilizado para buscar alavancar a sua carreira (algo bastante habitual na contemporaneidade). O tema do filme é a homossexualidade.

Prato, nos mostra um Jesus Cristo, dublando a cantora Glória Gaynor, cantando o sucesso I Will Survive; através de várias imagens, Jesus parece demonstrar estar desgostoso com a sua relação com Deus e, de alguma forma, se "rebela" deixando ver através dos seus gestos, enquanto perambula por Los Angeles, que ele é gay. Quando enfim, parece que Jesus "saiu do armário" e se libertou de Deus, um ônibus o atropela de forma inesperada e o vídeo termina.

The Greatest Action Story Ever Told, produzido pela Mad TV (2006), é uma narrativa em forma de trailer cinematográfico, que se pretende uma paródia. O seu título faz referência a The Greatest Story Ever Told (Stevens, 1965), conhecido filme sobre a vida de Jesus Cristo, rodado pelo cineasta George Stevens nos anos 60. Mas, a semelhança entre os filmes para aí, não há qualquer outra forma de citação estética ou narrativa que se possa encontrar entre as duas produções. Diferentemente dos outros dois vídeos citados, essa produção foi muito mais cuidadosa com a imagem gerada de Jesus Cristo; ela se deseja engraçada, cômica, no entanto, não desrespeitosa. Neste sentido, ironicamente, ela nos fala mais do Jesus tradicional que conhecemos do que os outros vídeos, e nos propõe perspectivas bastante interessantes para análise.

Sua proposta é simples, é uma chamada para que assistamos ao maior filme de ação jamais realizado. Neste filme a personagem Terminator, faz referência ao protagonista do filme $O$ Exterminador do Futuro2: o Julgamento Final/ Terminator 2: The Final Judgement (1992), de James Cameron, vivido pelo ator Arnold Schwazzeneger. A personagem voltou no tempo até a época de Jesus e lá faz ligeiras interferências bem ao seu estilo, ou seja, violento. No filme de James Cameron, o Exterminador, voltou ao tempo presente (anos 1990), para proteger um garoto que no futuro iria se tornar líder da resistência da luta da humanidade contra as máquinas. $\mathrm{O}$ robô protege o garoto a qualquer custo, simplesmente matando e

\footnotetext{
${ }^{1}$ O site de Javier Prato pode ser acessado em: http://www.javierprato.com/, acessado em 13/09/2012.

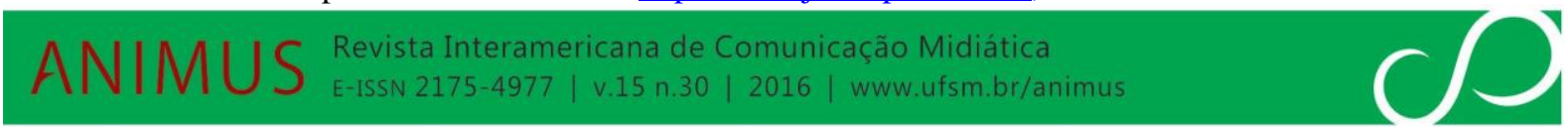


eliminando toda e qualquer ameaça. O menino se esforça para mostrar para ele que matar não é bom e nem justificável. Agora o "garoto" a ser protegido é Jesus Cristo. O Exterminador age no passado da mesma maneira como agiu no filme que lhe deu origem. Ao olhar com seus olhos robóticos para uma ameaça (se realiza um efeito visual para que assumamos o olhar da máquina) ele prontamente a elimina matando. Jesus acolhe o robô, mesmo por que não tem escolha, e passa a tentar dirimir a interferência dele no seu trabalho, neste sentido em alguns momentos ele tem de agir, não apenas salvando as pessoas de serem mortas, como também as ressuscitando ou explicando para o robô o motivo pelo qual ele não deve ser protegido.

A produção The Passion of Zombie Jesus, de Ira Hunter (2004, EUA), é na realidade um único plano sequência realizado para participação num concurso de Cinema Scrapshot, o seu realizador define o filme na página do Youtube como sendo: "Um filme bíblico blasfemo. O mais profano da história humana" (aqui gostaríamos de sugerir uma tradução melhor, ao invés de 'profano' a palavra profanador ficaria mais adequada às intenções do produtor).

Não há nenhuma motivação visível para que Jesus, no alto da cruz se transforme num Zumbi. Só poderemos especular, que para um jovem da contemporaneidade a estranha relação de ideais não seja nada impossível. O autor pode ter se inspirado no fato de que Jesus morreu, foi sepultado, e voltou, em corpo de carne, vivo ao terceiro dia. Bem, visto por olhos contemporâneos essa descrição cabe perfeitamente nos zumbis dos filmes de horror. Pessoas que são tidas como mortas e que depois se levantam de seus túmulos, mortas vivas, com seu corpo de carne apodrecendo, e saem perseguindo as demais para também torná-las zumbis.

Ora, qual a importância de se estudar estes vídeos? Qual a relevância de Jesus Cristo no montante de vídeos disponíveis no site Youtube? Quantitativamente qual o significado destes três vídeos no montante geral? Qual sua real relevância para o público? Quantas pessoas acessaram? Quantas gostam ou não gostam destas produções?

\section{QUANTIFICAÇÕES A PARTIR DO SITE YOUTUBE}

Como tratamos de três vídeos, interessou-nos saber qual a quantidade de vídeos cujo assunto fosse direta ou indiretamente ligados à figura de Jesus Cristo. No entanto, não há como procurar pela imagem, mas apenas pelas palavras chaves colocadas junto dela. Utilizamos como palavras chave o nome Jesus Cristo de diversas formas e idiomas (sem esquecer que Jesus também é um nome próprio). Relativamente aos idiomas ficamos restritos 
aos mais conhecidos em nosso país: português, inglês, espanhol, francês, italiano, alemão, chinês (simplificado/tradicional) e japonês. Os resultados obtidos, desde a fundação do Youtube, em fevereiro de 2005 até o nosso acesso em 18 de maio de 2012, foram os seguintes:

Jesus: 2.980.000 registros (resultados vieram em português, inglês e alemão), Jesus Cristo: 1.360.000 (em português), Cristo: 850.000 (em português); Jesus Christ, resultado: 2.630.000 (inglês), Christ: 1.110.000 (Inglês); Jesucristo: 126.000 (espanhol); Jésus-Christ: 2.690.000 (francês); Gesù Cristo: 26.800 (italiano), Gesù: 50.500 (italiano); Jesus Christus: 35.700 (alemão), Christus: 85.300 (alemão); em chinês simplificado, 耶稣基督: 32.000 , em chinês tradicional, 耶穌基督: 42.200; em japonês, イエス·キリスト: 9418/05/2012

As dificuldades relativamente às essas estatísticas são muitas. Uma delas é o fato de que o site traduz e procura equivalências para a palavra buscada. Colocamos o nome em alemão no campo de busca, p.ex., e chegam a aparecer vídeos em português. Nas buscas a campeã é a palavra Jesus, o primeiro nome é bastante semelhante em vários idiomas, além do fato de que é semelhante no inglês, o idioma internacional. Impossível, utilizando apenas o campo de busca do site Youtube, dizer quantos vídeos de fato estão lá alocados e registrados, que tratam da pessoa, do assunto ou da imagem Jesus Cristo. No entanto, como pensamos que não bastaria dizer milhares ou milhões de registros como faríamos coloquialmente, decidimos ao menos colocar os números para que se tenha uma idéia, mesmo que longínqua, do que este nome significa no buscador do Youtube, seguramente mais de 2,5 bilhões de vídeos. Em meio a estes bilhões de vídeos se encontram os nossos "três" vídeos. Cada um deles replicado, e republicado, no mínimo seis vezes cada um. Exceção feita a Passion Zombie, do qual foram encontradas apenas três reproduções. As republicações são úteis, uma vez que é através delas que algumas pessoas se decidem a legendar estes vídeos, adequando-os aos seus países de origem, possibilitando um maior acesso do público local.

Tendo em vista a dificuldade com estes levantamentos, principalmente quanto a sua utilidade real no que tange à quantificação, limitamos o nosso interesse aos três vídeos originalmente enviados. Assim, graças à contagem de visitas que o site Youtube faz, sabemos qual foi o número de acessos a essas estórias. Para tanto utilizamos o período de tempo decorrido desde a fundação do Youtube em fevereiro de 2005, até o nosso acesso, em 18 de maio de 2012. Dois dos vídeos analisados foram postados em 2006, mas nenhum destes foi realizado para a vinculação na internet, apenas Jesus Christ! The Musical foi realizado com 
esse fim em 2007. Logo abaixo dos vídeos há uma estatística que tenta registrar as pessoas que gostaram ou não gostaram deles. No entanto, sabemos, por experiência própria, que é possível clicar mais de uma vez, então na realidade não registra o número de pessoas, mas o número de cliques naquele item. Relativamente a estes vídeos os números ficam da seguinte forma, por antiguidade de postagem temos:

The Passion of Zombie Jesus (07':38'), 2004, enviado em 13/09/2006, teve 966.014 acessos. Das pessoas que acessaram, ficou registrado o fato de que elas clicaram 2.722 vezes em pessoa(s) gosta(m), e 2.590 em pessoa(s) não gosta(m), no período entre 13/09/2006 e $18 / 05 / 2012$.

The Greatest Action Story Ever Told (04':56'), 2006, enviado em 12/12/2006, produzido para Mad TV, possui 971.252 acessos. Recebeu cliques, Gostam: 3.613 e Não Gostam: 173. Encontramos mais seis republicações deste mesmo vídeo com nomes diferentes. As republicações são de datas diversas, todas com milhares de acessos.

Jesus Christ! The Musical (01':04’') (Javier Prato), enviado em 14/04/2007, possui 9.171.847 acessos, destes, clicaram Gostam: 26.490 e Não Gostam: 6.296.

Ocorre uma clara discrepância dos acessos recebidos por estes três vídeos. Os dois primeiros foram enviados ainda num estágio inicial do Youtube, o terceiro foi postado no momento de pleno desenvolvimento e interesse despertado pelo site, o que pode ter influenciado no seu maior número de acessos, no entanto, a discrepância, mais de oito milhões de diferença, é bastante grande, mesmo levando este fator em consideração.

Ao desejarmos quantificar o número de vídeos registrados no Youtube, o número de acessos e o número de pessoas que gostam ou não, descobrimos que saber quantos vídeos estão registrados e o número de pessoas que acessaram é uma tarefa impossível. Podemos saber apenas o que o site nos fornece: $\mathrm{O}$ número de vídeos registrados que respondem às palavras-chave da busca e o número de acessos. Ainda assim estes números nos são úteis, pois nos dão parâmetros.

Num primeiro momento já podemos verificar que a importância social destes três vídeos é muito relativa. Num universo de 2,5 bilhões de vídeos que respondem pela palavra chave Jesus Cristo, nossos vídeos podem ser reduzidos, mesmo replicados, a menos de vinte. Em termos numéricos eles são muito pouco significativos, e seu impacto social, no que tange à internet, pode ser praticamente irrelevante. 
São três propostas bastante distintas entre si, por essa razão escolhemos nos centrar em apenas um deles, o mais popular. Jesus Christ! The Musical, de Javier Prato (2007) é o mais popular, como foi verificado em seu número de cópias e de acessos. Antes de nossa análise, propriamente dita, uma outra questão se impõe: existe razão para se estudar uma imagem de Cristo gerada dessa forma? Há validade numa análise deste tipo?

\section{CRISTOLOGIA FÍLMICA}

Aqui não se trata apenas de verificar a personagem Jesus, mas sim a sua imagem resultante dos vídeos como um todo. Esta imagem é uma declaração sobre "Quem é Jesus", princípio básico que rege a Cristologia (CULLMANN, 2008, p. 19). Os trabalhos anteriores do teólogo Clive Marsh, nos fundamentam para tratarmos a elaboração de toda e qualquer imagem audiovisual, que "falam sobre Deus" ou que traduzem "A fala de Deus" para os homens, como sendo produtos teológicos (MARSCH \& ORTIZ, 1997, p. 22). Neste sentido, nenhum dos três vídeos elaborou uma imagem coincidente com as imagens ou títulos Cristológicos tradicionais, como: O Messias, o Profeta, O cordeiro de Deus, O Príncipe da Paz, O Filho do Homem, etc. No entanto, todos eles se traduziram em Cristologia Fílmica (VADICO, 2008).

A disputa pelo domínio da imagem de Jesus Cristo entre as religiões institucionalizadas e o Cinema ao longo do século XX, teve o cinema e a TV como os grandes vencedores. Através da elaboração da imagem de Cristo conforme as necessidades dos meios audiovisuais se possibilitou que, através da exploração do material fictício nos diversos filmes, Jesus fosse descolado da realidade religiosa na qual ele estava circunscrito ao longo dos séculos. Este descolamento da sua representação religiosa possibilitou que a sua imagem pudesse ser manipulada das mais diversas formas, com reações positivas ou negativas dos diferentes públicos que a receberam (VADICO, 2005). Contemporaneamente já há consciência de que uma coisa é a imagem do Jesus das religiões e outra é a sua representação pelos meios audiovisuais. A representação do Jesus dos meios audiovisuais é necessariamente dependente da imagem do Jesus religioso, enquanto o inverso nem sempre é verdadeiro.

Partamos, portanto, para a análise do vídeo Jesus Christ Musical, de Javier Prato. Primeiramente uma análise descritiva e técnica e em seguida uma exploração de seus significados, para só então estabelecer uma interpretação da imagem resultante. 


\subsection{Descrição e Análise Técnica do Vídeo Jesus Christ Musical}

Cena 1. O vídeo se inicia mostrando uma abertura que faz parte significativa da narrativa, pois nela ocorre uma música incidental que soa como religiosa e de meditação, nuvens passam rapidamente por um céu de fim de tarde, é o que é visto no primeiro plano. Cena 2. Ocorre uma fusão para o plano seguinte, que mostra a imagem de um libreto "Jesus Christ The Musical", as outras frases escritas não são legíveis. Cena 3. Terceiro plano, os acordes de piano, de introdução à música, surgem em som off sobre fundo preto, através do qual se fará uma transição, em fade out. Cena 4. No qual aparecem aos poucos por fusão a imagem de Jesus Cristo, sentado à beira mar, como se estivesse meditando. Começa a dublar (o som do fundo é a voz da cantora Gloria Gaynor, cantando I Will Survive), gesticulando de forma grandiloquente e exagerada, ligeiramente afetado. Cena 5. Ele aparece em primeiro plano com o por do sol e o mar como pano de fundo. Cena 6. Jesus aparece numa rodovia, mas é noite, ao mesmo tempo em que a palavra "noite" é dita na musica. Cena 7. Ele afirma que está "forte”, primeiro plano numa ponte, é dia novamente. Cena 8. Jesus aparece com a câmera tomando-o debaixo para cima, com alguns morros ao fundo e um grande céu azul de pano de fundo, o elemento natural ainda predomina. Classicamente, esta posição da câmera (contre-plongée) empresta "poder" à imagem da pessoa representada. Cena 9. Ocorre um corte abrupto localizando Jesus no Hollywood Boulevard, ele aparece em plano americano ${ }^{2}$, abrindo os braços e livrando-se espetacularmente de seu manto branco. Ele caminha sobre a calçada da fama, uma moça ao fundo olha incrédula. Ele continua caminhando pela calçada num plano sequência, filmado de frente, ele vem desfilando e gesticulando como se fosse uma Drag Queen ${ }^{3}$ fazendo uma performance, as pessoas em volta param e olham; Cena 10. Corte com quebra de eixo, plano médio, Jesus dá uma esbarrada de lado num pedestre, batendo-lhe com as cadeiras, provocando-o. Cena 11. Outro plano médio, ele continua em sua caminhada, passando pelo Shreck; Cena 12. Quebra de eixo, a mesma calçada, de braços abertos ele continua cantando e gesticulando. Cena13. Filmado debaixo pra cima, ele desce em plano médio uma escada rolante. Cena 14. Quebra de eixo, plano médio novamente na calçada; Cena 15. Quebra de eixo, plano americano, Jesus para e olha uma moça com uma cobra e fica

\footnotetext{
${ }^{2}$ Plano Americano, também conhecido por plano médio: o enquadramento é feito a partir da altura dos joelhos da pessoa deixando-se uma faixa de espaço sobre a cabeça.

${ }^{3}$ Drag Queen, nome que se dá a conhecidos personagens das noites gays que atuam como animadores de night clubs. São conhecidos pelo exagero tantos nos gestos quanto na vestimenta.
}

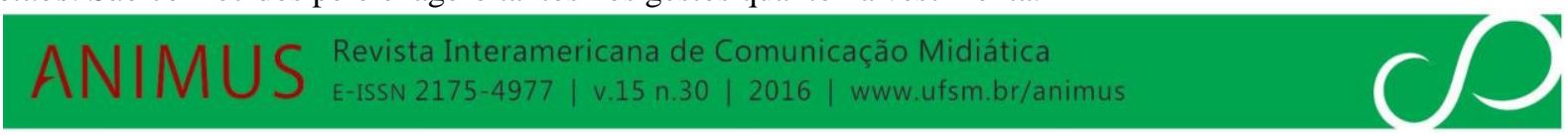


ao lado dela encarando-a. Cena 16. Quebra de eixo, Jesus continua caminhando, agora em plano geral, com um travelling que vem adiante dele, ele caminha e canta as últimas palavras da música e abre os braços de forma espetacular e desafiadora, um ônibus entra pela direita e o atropela, quando o ônibus acaba de passar não há ninguém lá. Cena 17. Fundo preto. Cena 18. Surge, em fusão, o retrato do ator vestido de Jesus Cristo e está escrito em volta como uma homenagem póstuma: "in loving memory" abaixo do retrato está escrito Jesus Christ e abaixo do nome vem entre parênteses o nome do ator (Miguel Mas); Créditos: depois os créditos são feitos sobre fundo preto através de fade in e fade out.

\subsection{Como as significações e sentidos são estabelecidos.}

Da Abertura até a Cena 5 o diretor jogou com um equívoco de interpretação. Ele anunciou um musical, utilizou em suas primeiras imagens um Jesus vestido da forma como se convencionou na arte e nos filmes de Cristo, colocou-o num pano de fundo de mar em fim de tarde, sentado em meditação, isso fez parecer que ele estava na antiguidade. Ele buscou ancorar a imagem criada na mesma que existe em nosso imaginário relativo à tradição da imagem de Jesus na cultura ocidental. No entanto, em pouco tempo somos levados a perceber que ele não está lá; nas Cenas 6,7 e 8 ele já aparece, nos dois primeiros, em locações urbanas contemporâneas, o que nos choca, a partir da Cena 9 ele aparecerá numa caminhada, onde desfila, ao mesmo tempo que dança e rebola como se fosse uma Drag Queen, trata-se de Hollywood Boulevard, ou a calçada da fama, como é mais conhecida.

Ao longo do seu desfile, o que mais ficou evidente foi o espanto registrado no rosto dos circunstantes, Jesus vai, de forma jocosa se insinuando e mexendo com a atitude das pessoas. Os cortes e as quebras de eixo aumentam relativamente de velocidade, até que no plano sequência final, Jesus, no auge da eloquente canção é atropelado por um ônibus.

Qual o significado de Jesus andar pela calçada da fama? Tendo em vista a letra da música e as suas atitudes, Jesus que é uma pessoa reconhecidamente famosa, trilha por onde grandes astros deixaram suas marcas, ele que é o astro por excelência; mas, na calçada da fama, por causa de seus gestos, por causa da música de Gloria Gaynor, ele parece estar assumindo a orientação homossexual. E isso chama muito a atenção das pessoas que estão à volta e são filmadas ao longo do trajeto que ele faz. Este esforço do cineasta de registrar a reação das pessoas, e até mesmo provocar estas mesmas reações é para nos levar à 
identificação com elas; reações estas que poderiam muito bem ser as nossas nesta mesma situação.

A linha narrativa é conduzida pela música de Gloria Gaynor, mesmo que alterada, é como se fosse uma voz off, ou um vídeo clip, no entanto narra uma estória. E é evidente que o protagonista a está dublando. A sua canção é uma espécie de desafio a Deus, a letra da música foi cortada e colada. Assim, o seu sentido foi ligeiramente alterado, dando a entender uma relação entre Jesus e Deus. Essa relação pode bem ser a de Pai e Filho, numa referência aos textos evangélicos. Jesus está claramente rompendo com Deus e assumindo sua vida.

A canção de Glória Gaynor (lançada em 1978, e escrita por Freddie Perren e Dino Fekaris) que originalmente retrata uma mulher que deseja superar o fim de um relacionamento é editada para que se adeque à relação de Jesus com Deus, assim a canção é retirada de seu contexto e sentido originais e ressignificada, mas ainda mantendo o seu sentido mais essencial, que é o de uma canção de rompimento e superação de um relacionamento. Podemos verificar isso facilmente na comparação da letra original abaixo ${ }^{4}$ com a parte que é utilizada no filme:

\section{Canção original:}

No início eu tive medo, fiquei paralisada

Fiquei pensando que nunca conseguiria viver

Sem você ao meu lado

Mas então eu passei muitas noites

Pensando como você me fez mal

E eu me fortaleci

E eu aprendi como me arranjar

E então você reaparece do nada

Bastou eu entrar para encontrar você aqui

Com aquela aparência triste no seu rosto

Eu devia ter mudado a droga da fechadura

Eu devia ter feito você deixar sua chave

Se eu soubesse, apenas por um segundo

Que você voltaria para me incomodar

\footnotetext{
${ }^{4}$ Para a letra original em inglês e as referências relativas à tradução vide: Letras.mus.br, acessado em 12/08/2012. http://letras.mus.br/gloria-gaynor/15949/\#traducao
} 
Bem, agora vá! Saia pela porta!

Simplesmente dê meia volta agora

Porque você não é mais bem-vindo

Não foi você quem tentou me machucar com o adeus?

Você pensou que eu me rasgaria em pedaços?

Você pensou que eu deitaria e morreria?

Oh não, eu não! Eu vou sobreviver!

Enquanto eu souber como amar

Eu sei que permanecerei viva

Eu tenho minha vida toda para viver

Eu tenho meu amor todo para dar

E eu vou sobreviver! Eu vou sobreviver! Hey, Hey!

Foi preciso toda a força que eu tinha

Para não cair em pedaços

E tentando duramente remendar os pedaços

Do meu coração partido

E eu passei muitas noites

Só sentindo pena de mim mesma

Eu costumava chorar

Mas agora eu mantenho minha cabeça bem erguida

E você vai me ver, como um novo alguém

Não sou aquela pessoinha acorrentada

Ainda apaixonada por você

E então você teve vontade de fazer uma visita

E só me espera pra ser livre

Agora estou guardando todo meu amor

Para alguém que me ame

Vá, agora vá! Saia pela porta!

Simplesmente dê meia volta agora

Porque você não é mais bem-vindo

Não foi você quem tentou me machucar com o adeus?

Você pensou que eu me rasgaria em pedaços?

Você pensou que eu deitaria e morreria? 
Oh não, eu não! Eu vou sobreviver!

Enquanto eu souber como amar

Eu sei que permanecerei viva

Eu tenho minha vida toda para viver

Eu tenho meu amor todo para dar

E eu vou sobreviver. Eu vou sobreviver!

Vá, agora vá! saia pela porta!

Apenas dê meia volta agora

Porque você não é mais bem-vindo

Não foi você quem tentou me machucar com o adeus?

Você pensou que eu me rasgaria em pedaços?

Você pensou que eu deitaria e morreria?

Oh não, eu não! Eu vou sobreviver!

Enquanto eu souber como amar

Eu sei que permanecerei viva

Eu tenho minha vida toda para viver

Eu tenho meu amor todo para dar

E eu vou sobreviver. Eu vou sobreviver!

\section{Versão do filme:}

No início eu tive medo, fiquei paralisada

Fiquei pensando que nunca conseguiria viver

Sem você ao meu lado

Mas então eu passei muitas noites

Pensando como você me fez mal

E eu me fortaleci

E eu aprendi como me arranjar

E então você reaparece do nada

Bastou eu entrar para encontrar você aqui

Com aquela aparência triste no seu rosto

(Corte na canção original)

Não foi você quem tentou me machucar com o adeus? 
Você pensou que eu me rasgaria em pedaços?

Você pensou que eu deitaria e morreria?

Oh não, eu não! Eu vou sobreviver!

Podemos perceber na letra original como é uma situação circunscrita e localizada entre duas pessoas e que diz respeito a uma relação específica homem e mulher. No corte que a música sofreu para ser adaptada à idéia do filme o que sobra da canção transporta esta idéia de "um relacionamento específico" para qualquer relacionamento, ou seja, amplia as aplicações do sentido e significado da letra. O Jesus que aparece com a canção é um sujeito que se diz abandonado e frustrado com uma relação. Conhecedores que somos da história de Jesus Cristo imediatamente transportamos as suas emoções expostas pela música para a sua relação com Deus. Tendo em vista que Jesus pregou e ensinou a palavra de Deus em concernência com sua vontade, a crucificação e o sentimento de abandono por parte de Jesus no Horto das Oliveiras, permite fazer esta relação sem grandes dificuldades.

Unindo os dados culturais de que esta é uma canção - que não foi feita para a comunidade homossexual, mas que foi por esta assumida - reconhecida como um "hino gay" e os gestos e trejeitos corporais de Jesus, a imagem que temos é a de um Jesus gay, e este Jesus é castigado por assumir a sua sexualidade. É evidente que aquela voz na canção é de Glória Gaynor, logo, Jesus está dublando a cantora, outra típica característica de shows que ocorrem em boites gays, onde era comum ocorrerem estas dublagens.

O pequeno vídeo que se pretende um musical - quando poderia no máximo se desejar um videoclipe - estabelece um tom de ironia desde o seu início. O título da canção é "Eu vou sobreviver!" No entanto é exatamente o contrário que ocorre ao final do vídeo com a personagem sendo atropelada por um ônibus. Não se trata tão somente de ironia, mas de castigo à revolta da personagem e à forma que essa revolta tomou.

\subsection{Os aspectos cristológicos envolvidos}

A imagem formada e resultante é a de um Jesus Gay, no entanto a mensagem é que nem Jesus pode ser gay, pois Deus castiga a homossexualidade e a rebeldia que, dizem alguns, ela significa às leis divinas.

Um primeiro diálogo entre a representação de Jesus e a condição homossexual, já havia ocorrido antes, ao menos no âmbito do cinema, em Jesus Christ Superstar (Norman Jewison, 1972). Neste filme, quando Jesus é levado para ser julgado por Herodes Antipas, a 
corte do rei é composta por pessoas vestidas com estereótipos de maquiagem e indumentária gay do início dos anos 70. Os gays do filme rejeitam Jesus e mandam-no embora, pois este se recusava a responder as questões colocadas por estes, logo ele era insuficiente (VADICO, 2005, vol. III: p. 53). No filme de Mel Gibson, A Paixão (2004) alguma proximidade entre a figura do diabo e a da homossexualidade pode também ser notada (o diretor escolheu estabelecer uma imagem andrógena desta personagem associando-o visualmente com o cantor Boy George [Culture Club], absorvido pela cultura gay dos anos 80 e 90; e remeteu novamente ao assunto no momento da flagelação de Cristo, no qual o diabo aparece carregando no colo paternalmente uma criança demoníaca e deformada; uma possível referência ao debate no Congresso Americano - naquele momento - da adoção de crianças por casais gays).

Ocorre ambiguidade na relação apresentada entre Deus e Jesus. Ficamos na dúvida se a relação é a de filho que quer se livrar do Pai, ou se a de um ex-namorado que tivesse tido um caso com Deus. Ocorrem as duas possibilidades. É indiferente a distinção, pois nas duas Jesus aparece como sendo gay e Deus como aquele que castiga a desobediência e a homossexualidade. Numa possibilidade ele é um namorado vingativo, na outra ele é um Deus punidor.

A imagem de Jesus, a sua vestimenta e aparência, é mostrada à maneira antiga e tradicional. Não importa que tudo ao redor seja contemporâneo, suas roupas são as da sua representação típica. Então também somos avisados que este homem está fora de lugar, de um jeito ou de outro. A sua representação é arrancada do local, do tempo e da história e jogada no lugar que elaborou as representações visuais e sonoras de Jesus Cristo, Hollywood. Este Jesus é evidentemente uma representação, ele é falso no que tange às religiões, mas é colocado no ambiente próprio da elaboração das suas diversas representações. E, enquanto representação, é verdadeira.

Então, se ele está fora de lugar, fora do seu tempo, e fora do seu discurso evangélico, podemos rir dele, mas não do Jesus dos Evangelhos, podemos rir deste, por que este não é aquele. Podemos rir do espanto das pessoas, com as quais nos identificamos, e finalmente rimos do castigo, da ousadia de uma "representação de Jesus" colocar-se como gay, e ela é castigada, da mesma forma que alguns pensam que os gays serão castigados por Deus por suas escolhas. 
É estranho como o grande esforço de Jesus por assumir sua sexualidade, termine num único e breve momento, sem nenhum aviso. Um colossal esmagamento, sem defesa. $\mathrm{Na}$ verdade, não se ri de Jesus, mas sim dos gays, pois se depreende deste vídeo: nem Jesus escaparia do castigo se ele fosse gay.

A disputa pelo domínio da imagem de Jesus Cristo entre as religiões institucionalizadas e o Cinema, teve o cinema, e posteriormente a TV, como os grandes vencedores. Enfim, através da elaboração da imagem de Cristo conforme as necessidades dos meios audiovisuais se possibilitou que, através da exploração do fictício nos diversos filmes, Jesus fosse descolado da realidade religiosa na qual ele estava circunscrito ao longo dos séculos. Este descolamento da sua representação religiosa possibilitou que a sua imagem pudesse ser manipulada das mais diversas formas, com reações positivas ou negativas dos diversos públicos que a recebiam.

No entanto, contemporaneamente, já há consciência de que uma coisa é a imagem do Jesus das religiões e outra coisa é a representação da imagem de Jesus pelos meios audiovisuais não religiosos. Não se está dizendo que essas imagens são completamente independentes e que elas não se interferem, elas se interferem e se alimentam. A representação do Jesus dos meios audiovisuais é necessariamente dependente da imagem do Jesus religioso, enquanto o inverso nem sempre é verdadeiro.

\section{CONCLUSÃO - UMA TEOLOGIA REFLEXIVA}

Essa proposta do diretor Javier Prato só é possível a partir do diálogo que mantém com a mais tradicional das imagens cristológicas, a de Jesus, o Cordeiro de Deus. Neste elaborado título cristológico, Jesus aparece como sendo o filho de Deus enviado a Terra para sofrer pelos pecados dos homens e redimi-los através do seu sacrifício na cruz. A estória da Redenção por excelência (CULLMANN, 2008: p 75). O vídeo de Prato ao mesmo tempo em que reflete esta imagem cristológica como um espelho, faz sobre a mesma uma reflexão. Em outras palavras, reenvia-lhe outra imagem, oriunda da primeira, mas não dela resultante. Trata-se de uma leitura crítica evidente. Pois se notarmos bem, Deus, o personagem que menos aparece na estória é o motivador, a causa, e o definidor do fim da narrativa.

Ora, como isto é possível? De um ponto de vista plausível para um leigo, mesmo com todas as justificativas teológicas paulinas, Deus abandonou Jesus no momento mais difícil e 
exigiu de um inocente um sacrifício em favor de desarvorados pecadores. Ele cruelmente sacrificou seu próprio filho. Jesus, tanto quanto numa leitura evangélica possível, surge e se mantém como uma vítima inocente.

Alguém de nossa contemporaneidade observa em Deus uma figura dura, vingativa e inflexível, incapaz de misericórdia com alguns milhões de indivíduos que compõe a nossa sociedade. E, o diretor, faz com que se ria disso tudo. Causa estupefação, riso, mal-estar e depois alívio. A situação é ridícula, este Deus é ridículo. De forma evidente, não é contra Deus que este diretor fala, mas contra uma determinada teologia que elaborou e sustentou esta imagem que parece fora de lugar no mundo contemporâneo.

Note-se que esta teologia popular, aqui dita reflexiva, propõe um evidente diálogo com a teologia proposta pelas instituições religiosas. Não apenas o vídeo de Prato, mas os outros dois ligeiramente comentados no início deste trabalho não se postulam pela negação do fato teológico, mas pela apropriação das ideias dele exaradas - e por ele possibilitadas - e pelo reenvio a estas mesmas instituições e sociedade do resultado das suas reflexões, e sentimentos, quanto esta imagem estabelecida. É oportuno, na contemporaneidade, que não apenas grandes diretores hollywoodianos estabeleçam imagens cristológicas, mas que todo aquele - e qualquer um - que desejar "falar sobre Deus" e sobre o que "Deus fala aos homens" possa fazê-lo efetivamente.

Para a nossa proposta inicial já temos uma resposta: E se Jesus fosse gay, zumbi, ou fosse salvo pelo Exterminador do Futuro? O que isto significaria? Significa que ele não é gay, nem zumbi e não foi salvo pelo Exterminador do Futuro. Estas imagens cristológicas geradas são contrassenhas para as institucionais propostas, e como contrassenhas elas pedem resposta, não para o seu conteúdo, mas para o seu desconforto e mal-estar com a tradição.

\section{REFERÊNCIAS}

A MAIOR História de Todos os Tempos/The Greatest Story Ever Told. Direção de George Stevens. Estados Unidos, 1965. 1 filme (173 min.): son.; color.; suporte DVD.

A PAIXÃO de Cristo/The Passion of the Christ. Direção de Mel Gibson. Estados Unidos, 2004. 1 filme (127 min.): son.; color.; suporte DVD.

CULLMAN, Oscar. Cristologia do novo Testamento. São Paulo: Editora Líber, 2001.

CULLMAN, Oscar. Cristologia do novo Testamento. São Paulo: Editora Hagnos, 2008. 
FERRARO, Benedito. Cristologia: Como compreender a vida, a prática, a morte e ressurreição de Jesus, O Cristo, Senhor, Libertador. Campinas: Ed. Pucc-Campinas, 2000.

JESUS CHRIST! The Musical. Direção de Javier Prato. Estados Unidos, 2007. 1 filme (01':04'”): son.; color.; suporte digital. Enviado em 14/04/2007. http://www.youtube.com/watch?v=WLKk00OYKhU

JESUS CRISTO Superstar/Jesus Christ Superstar. Direção de Norman Jewison. Estados Unidos, 1973. 1 filme (108 min.): son.; color.; suporte DVD.

MARSH, Clive \& ORTIZ, Gaye.org. Explorations in Theology and Film. Massachusetts: Blakwell Publishers Ltd., 1997.

O EXTERMINADOR do Futuro2: o julgamento final/The Terminator 2: the jugment final. Direção de James Cameron. Estados Unidos, 1992. 1 filme (153 min.): son.; color.; suporte DVD.

O Novo Testamento de Nosso Senhor Jesus Cristo e O Livro dos Salmos. Rio de Janeiro: Sociedade Bíblica do Brasil, 1974. Tradução de João Ferreira de Almeida.

TATUM, Barnes. Jesus at the Movies. Guide to the First Hundred Years. Santa Rosa: Polebridge Press, 1997.

THE GREATEST Action Story Ever Told. Produção de Mad TV. Estados Unidos, 2006. 1 filme (04':56'): son.; color.; suporte digital. Enviado em 2006.

http://www.youtube.com/watch?v=PFrufPxjwX0\&feature=related

THE PASSION of Zombie Jesus. Direção de Ira Hunter. Estados Unidos, 2004. 1 filme (07':38''): son.; p/b.; suporte digital. Enviado em 13/09/2006.

http://www.youtube.com/watch?v=tDENmSJIlMI\&feature=related

VADICO, Luiz. A Imagem do Ícone - Cristologia Através do Cinema. Um Estudo Sobre a Adaptação Cinematográfica da Vida de Jesus Cristo. Campinas, SP: [s.n.], 2005. Unicamp/tese.

VADICO, Luiz. Filmes de Cristo. Oito aproximações. São Paulo: Ed. a Lápis, 2009.

VADICO, Luiz. Cristologia Fílmica. Subsídios Teórico-metodológicos para a análise da produção de imagens Cristológicas geradas no cinema e na tv. In; Revista Alceu. V. 09 n. 17 - p. 47-63 Jul/Dez. 2008. Rio de Janeiro - RJ. 


\section{Luiz Vadico}

Licenciado e Bacharelado em História pela Universidade Estadual de Campinas (1993), mestrado em Multimeios pela Universidade Estadual de Campinas (2000) e doutorado em Multimeios pela Universidade Estadual de Campinas (2005). Atualmente é professor titular da Universidade Anhembi Morumbi. Supervisor do Centro de Estudos do Audiovisual (UAM). Professor de Comunicação, Estética e Cultura de Massa no curso de Extensão em TV para a Televisão Pública de Angola (TPA), em Luanda, Angola.

Esta obra está licenciada sob uma Licença Creative Commons. 